University of Nebraska - Lincoln

DigitalCommons@University of Nebraska - Lincoln

French Language and Literature Papers

Modern Languages and Literatures, Department

October 2006

\title{
Theatre and the Rwandan Genocide
}

Marie-Chantal Kalisa

University of Nebraska - Lincoln, mkalisa2@unl.edu

Follow this and additional works at: https://digitalcommons.unl.edu/modlangfrench

Part of the Modern Languages Commons

Kalisa, Marie-Chantal, "Theatre and the Rwandan Genocide" (2006). French Language and Literature Papers. 31.

https://digitalcommons.unl.edu/modlangfrench/31

This Article is brought to you for free and open access by the Modern Languages and Literatures, Department of at DigitalCommons@University of Nebraska - Lincoln. It has been accepted for inclusion in French Language and Literature Papers by an authorized administrator of DigitalCommons@University of Nebraska - Lincoln. 


\title{
Theatre and the Rwandan Genocide
}

\author{
Chantal Kalisa
}

In 1994, Rwanda was the scene of genocide, or more precisely in French, "le théâtre du génocide" (theatre of genocide). Perpetrators and victims played their role while the rest of the world watched the "spectacle" live on television. Perhaps because of its spectacular aspect, the Rwandan genocide has inspired a number of artistic materials. In the last decade, we have indeed witnessed the growth of literary and artistic expression in relation to the Rwandan genocide. Survivors and witnesses have told their stories in books and songs. Journalists, as well as other travelers "to the end of Rwanda," to use Véronique Tadjo's words, have borne witness to the genocide. Artists who were not there have also attempted to represent the "African genocide" and have cast themselves as participating in the process of reconciliation. I am referring in particular to the African writers who published their work in the context of "Rwanda: Devoir de mémoire," ("Rwanda: Duty to Remember"), a project where prominent writers were asked to visit Rwanda and "remain inresidence" with the expectation that they would write to generate creative responses to the genocide.

\footnotetext{
A t most, however, participants acknowledged these written texts had a limited audience in Rwanda. Rwanda is a primarily oral society. As a result, most people traditionally do not seek or receive written information. After publication, excerpts from several of the texts were adapted to the stage in Rwanda by Koulsy Lamko, a Chadian dramatist. Is there a body of artistic work we can refer to as theatre of the Rwandan genocide? If so, what would be its role?

On the literature of genocide, of disaster and catastrophe, Rubina Peroomian reminds us that we should understand it as a "unique body of artistic creations triggered by a traumatic, unprecedented collective experience in the history of [the Rwandan people]." It is my observation that theatre is present in Rwanda and is perhaps the most visible form of artistic expression. The subject matter often relates to the question of reconciliation as well as other economic, health, and social issues in post-1994 Rwanda. The idea of enacting genocide raises ethical questions such as how do you "create a spectacle" based on disastrous events?
} 
It appears, however, that theatre for the sake of recovery has become a natural tool in conflict and post-conflict areas. Such is the case of South Africa where a large body of dramatic expression exists in connection with the ongoing process of "Truth and Reconciliation." In Rwanda, many of those who initially produced written testimonials, novels, and films have felt compelled to adapt their work on stage. It is not uncommon to see theatre used during the April commemorations of the genocide in Rwanda, as well as among Rwandan communities in the Diaspora. Some documentary films on Rwanda bear aspects of theatricality when, for instance, during their testimonials, both survivors and perpetrators attempt to re-enact the events. The most disturbing example can be found in a German documentary entitled Der Mörder meiner Mutter (My Mother's Killer) in which Martin Buchholz follows Eugénie Musayidire's vivid confrontation with her mother's accused murderer. The perpetrator re-enacts the murder for Musayidire upon her insistent request. She, in turn, is seen imitating the gestures of her mother's assassin.

A tentative listing of the theatrical corpus about the Rwandan genocide includes written and non-written stage productions, radio theatre, produced within and outside the country by Rwandan and non-Rwandan artists. Radio theatre, such as the series Urunana, enjoys the widest audience because plays and sketches are primarily performed in Kinyarwanda. Radio is an ideal mode of mass communication in Rwanda because most households have access to it. The medium existed prior to the genocide; therefore, the public is familiar with it. The sizable number of radio-theatre productions before the 1994 genocide may enlighten us as to the nature of propaganda that led to genocide. In post-genocide Rwanda, there are productions by traveling troupes and by the University of Butare's art students. Ongoing projects by veteran professional groups such as Kalisa Rugano's Ballet Théâtre Mutabaruka, participate in national and international productions. Other dramatists include Jean-Marie Vianney Rurangwa and Jean-Marie Kayishema. Thanks in part to Koulsy Lamko's work at the University of Butare's Center for the Arts, we continue to see the rise of new creative initiatives, especially among younger Rwandan scriptwriters like Odile Gakire Katese, and religious-leaning Patrick Kamanzi's Ballet $d u$ Roi des rois/King of Kings.

$\mathrm{O}$ utside Rwanda, non-Rwandan artists have also written and/or staged their plays. The most widely known is perhaps $R$ wanda 94, a polymorphic and polyphonic theatrical presentation by the Belgian group Groupov, at the 1999 Festival d'Avignon. The play, which lasted six hours, was conceived and performed by a group of Rwandan and non-Rwandan artists. Real testimony of survivors and real media footage are mixed with elements of theatre such as music and actors on stage playing parts of journalists and thenFrench President Francois Mitterrand. The written version of this presen- 
tation has been published and includes analytical essays on theatre and its meaning in relation to genocide. Boubacar Boris Diop has adapted his novel Murambi: le livre des ossements (Murambi, the Book of Bones) to the stage in France, the United States, and his native Senegal. Elsewhere, Erik Ehn's Maria Kizito and Sonja Linden's I Have before Me a Remarkable Document Given to Me by a Young Lady from Rwanda (2003) are some of the plays that have been performed on stage in the United States.

Theatre in Rwanda, as is the case elsewhere, has its origin in daily rituals, as well as in rituals of life events such as birth, marriage, and death. Genocide, a unique event, forever obliterates these rituals: entire generations are lost, family lineage is destroyed, and community life disrupted. No society has readyprepared rituals to deal with the aftermath of such a collective experience of death and destruction. New rituals must be formed so that people can mourn their dead, properly commemorate the event, preserve the memory, and create a path to reconciliation. In the aftermath of genocide, daily rituals such as greetings are changed in this Manichean society where one is either a survivor or a perpetrator.

In the context of genocide, language, as scholars of the Holocaust have taught us, disintegrates. Communication is severely hindered. During the decades when the massacre of Tutsi was being prepared and carried out, communication among Rwandans was at best one-sided and limited to government-sponsored messages of hate. There was no dialogue, no debate, no forum, and thus no opportunity for dissent. The fact that the genocide occurred at all, committed by regular human beings, illustrates the lack of population input/feedback. Scholars and practitioners of performing arts have demonstrated how theatre can be used to restore language, and perhaps even move the nation toward fulfilling desired democratic ideals.

Koulsy Lamko is one person who realized the potential for theatre in post-genocide Rwanda. Like Boubacar Boris Diop, Lamko was a participant in the project Rwanda: Devoir de mémoire. He was born in Chad but was forced into exile because of war in his native country. He went to live in Burkina Faso, where he helped popularize the Theatre of Development. The multitalented artist has published several plays, stories, poetry, and critical essays. His novel La phalène des collines, a quasi-fabulist text, is his contribution to Devoir de mémoire. At the end of the project, Lamko immediately understood that presenting the work on stage was crucial. He subsequently decided to remain in Rwanda where he later founded the University of Butare's Center for the Arts. The Center's goals at the time were to promote the use of arts to advance peace, social justice, and reconciliation.

T amko has inspired a number of his Rwandan students to become practitioners of theatrical arts in their own right. During his tenure at the Cen- 
ter, Lamko experimented with various stage forms, particularly with Augusto Boal's Theatre Forum where participants could provide input to the process of reconstruction. In addition to arranging several workshops that brought in other professional artists, Lamko organized several presentations on urgent topics in post-genocide Rwanda such as conflict resolution, AIDS, women's rights and other social issues in post-genocide Rwanda. Lamko has staged conflicting views on what happened in 1994 and on what should happen after the genocide. In performances that lasted hours, he allowed the audience, mostly students, to intervene in case they disagreed or wanted to add to the debate.

Profoundly schooled in Boal's notions and methods of Theatre of the Oppressed, and a believer in Bertolt Brecht's theatre for change, Lamko sees theatre as a matter of survival for Rwandans and their culture. Lamko has stated in interviews that drama is important because it serves as a form of catharsis for victims of violence. Lamko wishes to provide the audience with the opportunity to rethink established ideas, such as the roots for hatred between Hutu and Tutsi. At the collective level, dramatic expression allows the community to heal by transforming collective traumatic experience into art. Theatrical expression is also cathartic at the individual level, both in terms of breaking the silence and body performance. We witnessed this kind of transformation during this conference when survivor Marie-Claudine Mukamabano ended her testimony in suspended silence but proceeded later to reconnect with her culture by performing Rwandan women's daily rituals, allowing the audience to witness theatre's healing potential.

As stated earlier, by definition, genocide annihilates everything, including the myths, symbols and language that define a community and its people. Theatre has the potential to encourage performers and the audience to envision new imagery, new language, and to reconnect with rituals. In Le gos au Rwanda: Entretien avec Koulsy Lamko, Lamko admits that part of his motivation to develop theatre in Rwanda was to help people regain the use of language and express outrage against genocide, war, and human rights violations. In addition to being the theatre of the oppressed, social theatre in Rwanda, as it is in other conflict areas, becomes a theatre of reconciliation, of debate, and of ideas.

Corps et voix: paroles rhizome (Body and Voice: Rhizome Words) (2000) and Le dernier jour d'un condamné à mort (Last Day of a Condemned Man), based on Victor Hugo's essay of the same title, are two of Lamko's representative adaptations in Rwanda. Both plays were a collaboration of the University's art students, as well as other professional actors. Rwandans were the expected major audience. The first play was presented in Butare with a mostly student audience, while the community at-large attended several times in the capital Kigali. Lamko subsequently presented his work in Europe. In 2002, I attended the second play in Kigali at the Franco-Rwandan Cultural Center. Rwandans 
watched it alongside members of the international community, sponsored by the French Embassy in Kigali.

C orps et voix: paroles rhizome was Lamko's first theatrical presentation in Rwanda. He composed the script by putting in dialogue excerpts from several works of the project Devoir de Mémoire. Stage delivery was in Kinyarwanda, French and some English to accommodate Rwanda's increasingly cosmopolitan public. Lamko's scripting included a scribe who narrates as the main storyteller and serves as some kind of chorus. Nine parts compose the play, which the author made available to me. In writing the dialogues, Lamko selected parts from the written novels and poetry that tell what happened in 1994, analyze the history of hate, and then set the path toward hope. Besides the dead, Lamko gives the floor to survivors, prisoners, and other witnesses. In the first part, the scribe recounts for the audience a creation myth. A female survivor taken from Monique Ilboudou's novel Murekatete laments why man cannot live without myth or the "Verb." She reminds the audience that her story is not a myth, punctuating the non-fictional aspect of the play. In the remainder of the play, Lamko attempts to re-create myths and revive the language. He incorporates tales from his own novel of the now famous Bisesero resistance in a segment called "Bissessero, l'épopée des victimes" (Bissessero, Victims' Epic).

Lamko's script also addresses the question "where was God" that most Rwandans seemed to ask while the massacre was occurring. The question is often recounted in many reports and testimonials and is based on a Rwandan saying that "God spends the day elsewhere but sleeps in Rwanda" (Imana yilirwa ahandi ikarara $i$ Rwanda). The question is where did God sleep during the genocide? One would naturally assume that this is part of natural questioning of the existence of God or an expression of anger toward God for failing to intervene. In the light of the annihilating force of genocide, this question is rather about a society's shocking discovery of the death of meaning in normal language, which goes hand in hand with the death of myths, rituals, and symbols that were part of Rwandan culture.

Language that defines a people loses its meaning in the act of genocide. As a result, how can Rwandans still claim the saying to be true? Lamko attempts to revive the language and myth in other ways. He adds dances and popular Rwandan songs to the script that set the body and voice in motion, calling to mind funerals and mourning rituals. In addition to the Bisesero episode, Lamko also recounts happy events through a wedding ceremony that permit people like Murekatete, cited earlier, to reconnect with rituals. Including familiar elements of Rwandan popular culture in the play elicit emotions that, as Lamko affirm, Rwandans had a terrible time achieving six years after the genocide. The play ends with a reminder that though the experience 
of genocide is beyond words, it is important to voice and listen to the "unsayable" in order to accomplish the work of remembrance (ibuka).

A s the title Corps et voix indicates, Lamko seems preoccupied with expressing what happened in 1994 with words and gestures, and how this affects the victim and survivors. In Le dernier jour d'un condamné à mort, Lamko engages a topic of national debate of the time, the system of Gacaca. These courts, based on traditional courts of the same name, have been re-created to alleviate the overwhelming tasks of trying an unimaginable number of accused in Rwandan prison.

Written in the nineteenth century, Hugo's text was part of the author's lifelong fight for human rights - a plea for the abolition of the death penalty in France. The text has since been adapted on stage many times. While 2002 was the bicentennial of Hugo's birth, such a text and its performance in Rwanda takes a particular meaning in addition to the universal plea for human rights. Hugo's protagonist is a prisoner who reveals his thoughts to the audience as he is about to die for his crimes. While admitting his guilt of a horrific but never identified crime, he nevertheless makes observations about the meaning of such a punishment for his family and for the French society in general. In June 2002, as Lamko staged a story of a man who wanted his life spared, the debate over Gacaca courts peaked. Lamko's staging should be understood in the connection to Rwanda's impasse and subsequent need for creativity in the process of justice and reconciliation. Like Hugo, Lamko's "Rwandan character" never reveals his crime, although the allusion to genocide perpetrators is apparent in the adaptation.

To adapt the text, Lamko chose to "rwandicize" the context once again. The setting remains universal: a prison cell with little decoration, and a man wearing typical prison clothes seated on a prison bed. The prisoner interacts only with a guard and a priest. Otherwise, the script is largely composed of the prisoner's monologue. Lamko's choice of actor for the main character reflects the desire to specifically contextualize the content of the universal text. The main actor was trained to speak French with a recognizable Rwandan accent. Lamko admits that he had even originally sought to use a real prisoner accused of genocide, but changed his mind after an expected uproar.

Another way Lamko addresses specific Rwandan circumstances was the inclusion of background voices whose words do not divert from the original. But again here, the dramatist makes sure that the voices heard are distinctively Rwandan. All actors perform with specific movements, smile, tone associated with Kinyarwanda speakers. Le dernier jour du condamné becomes polymorphic when Lamko proceeds to insert Rwandan music, performed by Rwandan musicians in what could be described as the orchestra section on the left side between the stage and the audience. The musicians remain in this space during the entire play. A young Rwandan woman occasionally dances to the music, while crossing in front of the audience. The music and dance 
are remarkable, but do not upstage the main point of the story - the voice of the perpetrator. As mentioned before, this play was done during a time when Gacaca Courts were proposed as a possible solution to the enormous challenge of how justice can be conducted in post-genocide Rwanda. The subject matter of the play becomes an appeal for Rwandans to consider all perspectives during the ongoing debate, including that of an admitted criminal.

In conclusion, Lamko's contribution to theatre should be interpreted in the context of a larger framework, as a part of the global community's efforts to prevent war and violence. Lamko's relative success in Rwanda is due partially to the fact that he worked within the university setting that, by definition, gathers people who are more open to new visions and concepts. A more complete assessment will have to consider work done outside the university. It remains to be seen, however, whether his work and others like him will result in lasting peace for individuals and for communities. Additionally, it is important to remember that much cannot be done without contribution and encouragement from outsiders. Although the art world has felt the urgency to respond to the genocide, it is crucial to keep in mind that Rwandans will carry a heavy emotional burden for generations to come. Thus, attempts to represent the story of the Rwandan genocide should refrain from trivialization.

\section{Recommended Readings}

Boal, Augusto. 1979. The Theatre of the Oppressed. New York: Urizen Books.

Diop, Boubacar Boris. 2000. Murambi: Le livre des ossements. Paris: Stock.

Gallimore, Rangira Béatrice and Chantal Kalisa, eds. 2005. Dix ans après: Réflexions sur le génocide rwandais. Paris: L'Harmattan.

Ilboudo, Monique. 2000. Murekatete. Bamako: Le figuier.

Lamko, Koulsy. 2000. La phalène des collines. Butare: Kuljaama.

Mukagasana, Yolanda. 1997. La mort ne veut pas de moi. Paris: Fixot, 1997.

Mukagasana, Yolanda. 1999. N'aie pas peur de savoir - Rwanda: Une rescapée tutsi raconte. Paris: J'ai lu.

Mukagasana, Yolanda. 2001. Les Blessures du silence. Témoignages du génocide au Rwanda. Arles: Actes Sud et Médecins Sans Frontières.

Mukagasana, Yolanda. 2003. De bouche à oreille. Paris: Editions Menaibuc.

Peroomian, Rubina. 1998. "Problematic Aspects of Reading Genocide Literature: a Search for a Guideline or a Canon." in Richard G Hovannisian (ed.), Remembrance and Denial: The Case of the Armenian Genocide. Detroit: Wayne State University Press.

Tadjo, Véronique. 2002. L'ombre d'Imana: voyages jusqu'au bout du Rwanda (translated into English under the subtitle The Shadow of Imana: Travels in the Heart of Rwanda). Oxford: Heinemann.

Chantal Kalisa is Assistant Professor of Francophone Studies at the University of Nebras$\mathrm{ka}-\mathrm{Lincoln}$. She has published several articles on the representation of violence in Francophone literatures. She recently co-edited a book Dix ans après: Réflexions sur le génocide rwandais (2005), a volume of critical essays and creative writings on the genocide. Correspondence: Modern Language \& Literature, 1111 Oldfather Hall Lincoln, Nebraska 68588, USA. E-mail: mkalisa2@unl.edu 